\title{
Knowledge management and organisational culture in higher education institutions*
}

\author{
Doris Gomezelj Omerzel, Roberto Biloslavo, Anita Trnavčevič**
}

This paper focuses on the higher education area in a small Central European country. Its purpose is to explore the concept of culture, the concept of knowledge management (KM) as well as the correlations among their dimensions at the university level. Since we assume that it is educational personnel who is involved in KM processes, our research covered the teaching staff. Our questionnaire is based on a similar research carried out by Wilkens et al. (2004). The literature is reviewed and the empirical analysis is performed in order to examine and to explain the relationship between organisational culture and knowledge management. The findings presented in the paper can be important for further development of the higher education sector in Central and Eastern European countries as well as for other profit oriented industries.

Dieser Artikel beschäftigt sich mit dem Bereich der höheren Bildung in einem kleinen mitteleuropäischen Land. Ziel ist, die Konzepte von Kultur und Wissensmanagement, sowie die Zusammenhänge zwischen ihren Dimensionen auf der universitären Ebene zu untersuchen. Da wir der Meinung sind, dass der Wissensmanagementprozess im Bildungswesen besonders das Personal betrifft, fokussiert unsere Untersuchung auf das Lehrpersonal. Unser Fragebogen basiert auf einer ähnlichen Untersuchung von Wilkens et al. (2004). Neben einer Betrachtung der Literatur wird eine empirische Analyse durchgeführt, um die Beziehung zwischen Organisationskultur und Wissensmanagement zu untersuchen bzw. zu erläutern. Die Ergebnisse dieser Studie können für die weitere Entwicklung der höheren Bildung in Mittel- und Osteuropa wie auch für profitorientierte Organisationen bedeutsam sein.

Key words: knowledge management, organisational culture, higher education, knowledge, KM processes

* Manuscript received: 19.05.10, accepted: 14.11 .10 (1 revision)

** Doris Gomezelj Omerzel, Assistant Prof., Faculty of Management Koper, University of Primorska, Slovenia. Main research areas: Entrepreneurship, management and tourism. Corresponding address: doris.gomezelj@fm-kp.si.

Roberto Biloslavo, Prof., Dr., Faculty of Management Koper, University of Primorska, Slovenia. Main research areas: Knowledge management, strategic decision, strategic innovation and change.

Anita Trnavčevič, Prof., Faculty of Management Koper, University of Primorska, Slovenia. Main research areas: qualitative research methodology and education policy. 


\section{Introduction}

Educational reforms in EU in the last decade were coloured by choice, decentralisation, deregulation and devolution of power. Higher educational institutions (HEIs) have - it seems in parallel with the Lisbon strategy, the Bologna processes and the internationalisation and Europeanization of $\mathrm{HE}$ (Teichler 2004; Beckmann/Cooper 2004) - become to be seen as a 'business', or better expressed as a 'service business' (Hemsley-Brown/Oplatka 2006; Oplatka 2004; Goldsmith 2004) which should expand beyond the national borders and attract international students. Hence, higher educational institutions (HEIs), just as any other organisation that operates in a dynamic environment, have to respond rapidly to changing environments in order to survive. A number of different external drivers of change regarding $\mathrm{HE}$ have been cited in the literature (Bates 1997; Levine 2000; Middlehurst/Woodfield 2006), these are: the radical shift from an industrial to a knowledge society, government's demand for usable knowledge and cost efficiency, demographic changes, market pressures from industry, internationalization of higher education, lifelong learning, the paradigm shift from teaching to learning, new technologies, and globalization. All these drivers bring new challenges to HEIs, which can be partly solved by adopting forms and practices used in private and corporate management, especially regarding forms of educational governance (Meyer 2002), but in the largest part only effective KM seems to be the appropriate solution. Anyway, the role of the HEI is more and more to create change and not (only) to respond to it. Today, universities are facing new competitive forces. We have entered an age of knowledge in which educated people and their ideas have become strategic commodities essential to our security, prosperity, and social well-being. As the 21 st century opens, tertiary education is facing unprecedented challenges, arising from the convergent impacts of globalization, the increasing importance of knowledge as a principal driver of growth, and the information and communications revolution. Tertiary education is indeed central to the creation of the intellectual capacity on which knowledge production and utilization depend, and to the promotion of the lifelong-learning practices necessary for updating people's knowledge and skills. Salmi (2002) clearly believes that the tertiary education sector must play a central role in preparing societies for new times.

We cannot properly discuss about $\mathrm{KM}$ if we do not consider its relation to organisation culture. Different authors underscore the importance of linking cultural and organisational factors to the implementation and sustainability of knowledge management initiatives (Davenport/Prusak 2000; De Long/Fahey 2000; Gupta/Govindarajan 2000). Constrained by its environment, an organisation makes a number of "choices" which, collectively, eventually define its culture. These choices are influenced by the philosophy of the organisation, the values of top management, and the "assumptions" of founding principles and succeeding generations of organisational leaders. These choices also define 
the success or failure of KM initiatives (Balthazard/Cooke 2004). In organisations such an organisational culture should be created that incorporates $\mathrm{KM}$, including motivation, ability, performance, education, learning, training, trust, behaviour, values and beliefs (Morris 2000; Sveiby 1998; Cloete/Snyman 2003). A culture where employees are encouraged and supported to share and re-use knowledge in general should be created.

Based on that we can conclude that people within HEIs have to accept some common rules and ways of doing, which are part of the organisational culture, if they want to effectively work together, learn, and share knowledge.

In the modern economy successful organisations are organisations which create, store, share and embody new knowledge in the form of new or improved products and services. According to Grant (1996) knowledge management consists of knowledge generation, application and exploitation. Knowledge management involves efforts to maximize company performance through the creation and exchange of knowledge. Knowledge management is especially important for organisations that are comprised of experts (Dawson 2000), where success depends upon the generation, utilization, and uniqueness of their knowledge base (Donaldson 2001). Such institutions are characterized as having knowledge as both their main production factor and their final product (Goddard 1998). It would seem appropriate to consider higher educational institutions as organisations comprised of experts.

The aim of this paper, then, is to develop a better understanding of the relationship between organisational culture and KM processes in HEIs by empirical analysis of two HEIs in Slovenia, a small central European country. The Competing Values Framework devised by Quinn and Rohrbaugh (1981) was used to analyze the differences in organisational culture profiles and how they might be related to the various KM processes. Such an understanding would enable practitioners to be aware of the impact different cultural types might have on KM processes in HEIs and, based on that, prepare possible future activities for better managing scholarly knowledge in a certain cultural setting or changing organisational culture through appropriate initiatives.

\section{Background}

\section{Knowledge and knowledge management processes}

Knowledge management constitutes a planned activity in an enterprise and encompasses the identification of key knowledge, generation of new necessary knowledge, and transfer of knowledge between and among employees. All these processes must be embedded in the overall functioning of organisations, must form an integral part of the culture of knowledge, and, in particular, must be based on relevant information technology. Considering the great extent to 
which knowledge management relates to employees, knowledge management must be harmonized with human resources management policy.

The key theories, which contributed considerably towards the understanding of the importance of knowledge for organisations are the theory, based on resources (also Source-based theory or RBT) and the theory, based on knowledge (also knowledge-based theory or KBT). The knowledge based view supposes that the capability to create and utilize knowledge is the most important source of sustainable competitive advantage (Grant 1996; Kogut/Zander 1992; Nonaka 1991; Prahalad/Hamel 1990). Knowledge in organisations should represent the foundation on which company strategy is built. This means that knowledge should be understood as the fundamental factor of sustained performance (Grant 1991; Spender/Grant 1996; Spender 1994). Management support is the most important factor of systematic knowledge management. The growing importance of knowledge naturally calls for its systematic management. We have reached recognition of the need to understand and to measure the knowledge management activities with the objective that organisations can do what they do better, and so that governments can develop and adapt policies to promote these benefits. Systematic knowledge management in the organisation includes efforts to maximise the success of the organisation through the creation and exchange of knowledge and skills. Lately, new definitions of management and its role in knowledge management have been developed (Drucker 2001; Sveiby 1997). In order to be able to manage knowledge, one has to understand what knowledge is and how to make efficient use of it. Efficient knowledge management has gained importance because of the very need of the organisations who wish to perform successfully in a competitive market to maximize the efficient use of all of their resources (Suresh 2007). The goal of knowledge management is not knowledge itself, but rather the management of human resources who possess such knowledge. Pundziene et al. (2006) emphasized that human resources management was one of the significant challenges throughout all the stages of the organisation lifecycle. One of the relevant elements of knowledge management is undoubtedly the creation of such an environment in which individuals trust one another and the management and are willing to share their knowledge with others with a view to contributing to the successful performance of their organisation (Kermally 2007).

Quintas, Lefrere and Jones (1997) define knowledge management as a process of continuous management of all types and forms of knowledge with a view to realizing the set goals, fully exploiting existing knowledge and creating new opportunities. Similar to this is the definition given by Duffy (2001), according to which knowledge management constitutes a formal process which ensures efficient simultaneous use of knowledge by employees, technology and work process and the transfer of knowledge to the right individuals at the right time. Brooking (1998) also understands knowledge management as a certain activity 
which is consistent with the human capital management strategy. Macintosh (1999) understands knowledge management as a process of identification and analysis of available knowledge and, consequently, as a process of planning of different activities with a view to realizing the set objectives and increasing a company's capital. Wiig (1997) defines knowledge management as support for knowledge-related managerial activities, such as creation, storage, reformulation and use.

In our study we propose and use a knowledge management model based on four processes: knowledge generation, storage, transfer, and application. Knowledge generation involves the internal and external environment of the organisation. To be effective in the process of generating knowledge the organisation should start by determining the knowledge necessary for achieving the goals (brainstorm sessions, interviewing clients, suppliers or colleagues), identifying the knowledge available (it is obviously important to know what knowledge is already available in the organisation), determining the knowledge gap, developing the knowledge themselves (based on the difference between the necessary and available knowledge); this can be done through education and training, performing research and development or by means of customer satisfaction studies.

All participants must be actively engaged in the process of generating knowledge of an organisation. As communication between employees contributes to the transfer of knowledge, it is necessary for the organisation to create a culture which encourages communication. Sharing knowledge may play a significant role in increasing one's exposure to different ideas and providing different sources of information. Information and knowledge transfer at both the individual and organisational level is as such an important factor that fosters innovation (Dakhli/De Clerco 2004). One can imagine knowledge transfer as flows of individual knowledge fragments in the network of employees/coworkers. Social interaction and employees' desire to cooperate play an important role in this sense. Knowledge can be transferred in a single stage, i.e. directly from the transmitter to the recipient. The transfer of knowledge also depends on the development of an atmosphere of trust and collaboration. Creation of knowledge is a costly affair, and that is why it is critical for organisations to store the knowledge, and provide access to it, in a professional and efficient manner throughout the organisation for leveraging it in order to achieve sustainable competitiveness (Pillania 2008). Open access to the knowledge base should be ensured. The most important aspect, however, is the manner in which knowledge is stored: it should allow for a rapid and efficient search for and, in particular, updating of knowledge (Marquardt 1996). In order to be able to store knowledge, one usually collects and processes it in electronic form, part of it can be stored in the form of books, handbooks, documents and plans, while part of it, usually tacit knowledge, remains with employees. 
Modern information technology and software allow for an almost unlimited storage of knowledge.

When we think or do something, we apply knowledge. If we want to do something new, we need ideas about what to do and how to do it. Ideas are building new knowledge, which can be used within all kinds of processes. It is only by applying knowledge that one creates its direct utility value within a company. Since one also creates new knowledge when applying existing knowledge, one continually returns to the initial stage of knowledge management, i.e. the generation of knowledge which is repeatedly followed by the transfer and storage of knowledge. Knowledge management phases are ever recurring. One should continuously encourage employees to apply knowledge. If an organisation succeeds in increasing the application of knowledge among employees, it means that its knowledge management is successful and efficient.

Within the HEI knowledge exists in many forms. However, we focus on the knowledge of academics that includes professional knowledge, teaching skills as well as research capabilities. While we present the four processes in successive manner for convenience of discussion, we emphasize that there exists considerable interdependency among them.

New knowledge that is created in the knowledge generation process needs to be stored for later use as an organisational memory. The process of knowledge storage within an organisation allows for the creation of a quality knowledge base which must contain an organisation's overall applied knowledge. The knowledge base must be made accessible. It is of major importance that knowledge is stored in such a manner as to allow for a rapid and efficient search and, in particular, the update thereof (Marquardt 1996). In order to be able to store knowledge, one usually pools knowledge and processes it in electronic form; also, some knowledge may remain in the form of books, manuals, documents and plans, while one part of knowledge, usually tacit knowledge, is retained by employees. Modern information technology and software allow for an almost unlimited storage of knowledge. A company must decide on the type of storage that best suits its needs. An electronic knowledge base is a rather efficient tool for knowledge storage; however, it does require a sound organisation and regular updates and, in particular, must be made accessible to employees (Probst et al. 1999). Considering that knowledge is rendered obsolete rather rapidly, the knowledge base must be regularly followed and monitored with a view to establishing whether or not it corresponds to the actual situation. To this end, Drucker (1993) proposes knowledge inventories allowing for a systematic removal of outdated knowledge from an organisation, i.e. from both the knowledge base and the employees' consciousness.

Dissemination of the overall available knowledge throughout an enterprise presents its employees with opportunities to gain new knowledge. Knowledge is of the greatest value to a company when it is being used by as many employees 
as possible. Ideas have maximum impact when the majority of employees, and not only a small group of individuals, are acquainted with them (Garvin 1993). In other respects as well, communication between employees contributes to knowledge generation, for which reason it is necessary for an enterprise to create a culture which encourages communication.

As new knowledge is being generated through the application of existing knowledge, one continually returns to the two initial stages of knowledge management, i.e. acquisition and creation of knowledge, which are again followed by knowledge transfer and knowledge storage. One can see that the phases of knowledge management are ever-recurring. One must continually encourage employees to apply knowledge. Thus, one facilitates invention and thereby the application of knowledge in new or updated products or services (Probst et al. 1999). We can conclude that "KM processes are heavily influenced by the social settings in which they are embedded and are subject to various interpretations based upon organisational norms and social interactions among individuals" (Alavi et al. 2006).

\section{Organisational culture}

Tylor (1871) was the first scholar who defined culture. He claimed that culture is "that complex whole which includes knowledge, belief, art, moral, law, custom, and any other capabilities and habits acquired by man as a member of society". An extended form of this definition more than a century later is offered by Schein (1992) who described culture as "a pattern of shared basic assumptions that the group learned as it solved its problems of external adaptation and internal integration, that had worked well enough to be considered valid, and therefore, to be taught to new members as the correct way to perceive, think and feel in relation to those problems". Organisational culture is the system of assumptions, values, convictions and beliefs accepted and commonly interpreted by the members of the organisation. It reflects both the real and the declared values of the company and its members (Zsóka 2007).

Referring to these definitions, we can conclude that organisational culture is a set of explicit and implicit rules of what is and is not acceptable behaviour in an organisation, influenced by core values, norms and underlying assumptions.

Among many different models of organisational culture (Handy 1993; Deal/Kennedy 1982) we considered the Competing Values Framework (CVF) developed by Quinn and Rohrbaugh (1981) as a proper framework for organisational culture analysis based on the psychological archetypes. Quinn and Rohrbaugh (1981) named four quadrants of the framework as hierarchy, market, clan, and adhocracy. The hierarchy culture type represents a wellstructured and formalized organisation, where formal procedures, rules, policies and clear expectations bind the organisation together. The main strategic tasks are maintaining the stability and smooth-running of the organisation which will 
ensure the organisation's efficiency. The market culture type represents an organisation as a market. This means it is open to the external environment and there are numerous transactions which enable the organisation to gain competitive advantage and market leadership. Such an organisation is strictly goal oriented and operates by market rules. The main values are competitiveness and productivity. The clan culture type is like an extended family where everyone takes care of each other, and it is a nice place to work. Such an organisation is therefore tightly connected and teamwork prevails. The main strategic objectives are building the commitment through mentorship which enables personal growth and a positive working climate. The adhocracy culture type is a very dynamic and creative place to be. Therefore the organisation is very flexible, which enables innovations, growth and the gaining of new resources.

\section{HE Is, KM processes and organisational culture}

Serban and Luan (2002) claim that "colleges and universities exist to create and share knowledge". HEIs are about the creation, transformation and transmission of knowledge (Laudon/Laudon 1999) or, as Clark (1984) would say, "clusters of professionals tending various bundles of knowledge". HEIs are also specific, because knowledge is their input and also output. Therefore the greatest challenge to modern HEIs is to meet the needs of the academic staff who are simultaneously developers, users, and bearers of high level knowledge, and generators and learners of new knowledge.

Tippins (2003) stressed that managing knowledge in HE is often very difficult because of several bureaucratic and cultural factors which present obstacles. There is a lack of social interaction which influences effectiveness of the communication process and the creation of social networks, and also a lack of interest because of complacency and disengagement from the learning process. $\mathrm{KM}$ is one of the main priorities of the HEIs, since the main purpose of KM, according to Wiig (1997), is maximization of the organisation's knowledgerelated effectiveness and returns from its knowledge assets and their constant renewal. Knowledge management in HE can be defined as "the art of increasing value from selected knowledge assets", which could improve its effectiveness (Geng et al. 2005). Wiig (1997) claims that "faculties within universities and other learning institutions have been concerned about knowledge transfer processes and the creation and application of knowledge for several millennia". Similarly, Rowley (2000) writes that the educational sector has always been recognized as the focal point for various knowledge processes, namely, knowledge creation, dissemination and learning. We believe that effective knowledge management is of vital importance for: increasing the quality and efficiency of education and research, for retaining the best professors and researchers, for developing new curricula, for improving cost efficiency and for 
exceeding the limits of time and space allowing for the fulfilment of student expectations anywhere and at anytime.

University leaders are increasingly becoming more aware of the concept of culture and its significant role in university change and development. Further, universities possess distinctive characteristics, which correlate strongly with their respective cultures (Bartell 2003; Sporn 1999). At the university level, culture can be defined as the values and beliefs of university stakeholders (i.e., administrators, faculty, students, board members and support staff), based on tradition (Deal/Kennedy 1982; Bartell 2003). Values and beliefs are thought to greatly influence decision-making processes at universities (Tierney 1988; Bartell 2003) and shape individual and organisational behaviours. Different existing empirical studies confirm the existence of a positive correlation between the types of organisational culture (according to the CVF model) and knowledge management processes (Lawson 2003; Sharimllah et al. 2007). An effective KM can be characterised by an environment where people at all levels unselfishly contribute their knowledge to the collective good (Israelsohn 1999).

The main obstacle to effective implementation of knowledge management in HEIs is the basic nature of these organisations. Although it is generally accepted that knowledge is an asset that increases in value when shared by individuals, it is interesting to observe that many faculty members consider knowledge to be their private property (Wind/Main 1999). This predominant orientation within HEIs persists in spite of the empirical research that confirms the most successful cultures as being those that support both group cooperation and individual achievement (ASHE 2003). The fact is that knowledge is considered as a possible source of individual differentiation (Wiig 1993) that gives power to whoever possesses it. This is why knowledge is not shared freely between faculty members, and in some cases knowledge may even be lost.

Using knowledge management processes in higher education is as vital as it is in the corporate sector. If done effectively, it can lead to better decision-making capabilities, reduced "product" development cycle time (for example, curriculum development and research outputs), improved academic and administrative services, and reduced costs. Relying on the institutional knowledge of unique individuals can hamper the flexibility and responsiveness of any organisation. The challenge is to convert the information that currently resides in those individuals and make it widely and easily available to any faculty member, staff person, or other constituent. Higher education is moving towards the culture that is ready to embrace knowledge management (Kidwell et al. 2000). Indeed the cultural factors will impact knowledge management practices (Karoliny et al. 2009).

We can conclude that, although HEIs are educational and research institutions at the same time, and therefore knowledge is their main input and also output, the impact of organisational culture on KM processes is still very strong. This 
does not differentiate $\mathrm{HE}$ institutions from other organisations, on the contrary it reinforces the notion that HE institutions are the ideal place for considering and researching KM processes.

\section{Empirical research}

Our guiding research question in empirical research was: What culture does exit in Slovenian HEIs and what is the 'status' and understanding of KM? We designed a quantitative study. Our decision about research design was based on our experience in previous research that academics in Slovenia are not willing or ready to participate in interviews and/or observations. Recently, students who are doing empirical research report problems with doing any research, for the most 'promising' is still quantitative study.

\section{Sampling}

There are 3 public universities in Slovenia, 44 public faculties and about 110 000 students enrolled in public HE institutions. We focused our study on the teaching staff of faculties, and selected 2 public faculties from the area of social sciences, using two criteria.

The first criterion applied was the number of enrolled students, and the second was the level of the implementation of ICT (Information and Communication Technology) in support of learning and teaching at HEIs. The reason for the application of the first criterion was the assumption that institutions with a higher number of enrolled students would participate more readily in our research, considering that institutions facing underenrollment focus, as a rule, more frequently on solving the issue of underenrollment and, consequently, their financial difficulties. The selection of the second criterion was based on the assumption that an efficient application of ICT significantly affects the efficiency of KM processes (Syed-Ikhsan/Rowland 2004). ICT constitutes an important support for knowledge storage and transfer. An intensive use of ICT may result in employees performing more of their work at home or anywhere outside institutions. Consequently the establishment of social networks, which are necessary for the development of institutions, is rendered more difficult. On account thereof, the conditions allowing for an efficient knowledge transfer are impaired and, in addition, the establishment of trust between employees is rendered especially difficult.

Since we are of the opinion that it is the very educational personnel that are involved in KM processes, our research covered the teaching staff. Namely, the teaching staffs are the employees responsible for knowledge acquisition through research and otherwise, as well as for knowledge dissemination through lectures and various forms of counselling. We forwarded our questionnaire via email to all educational employees of both institutions. Each of them was asked whether 
they preferred to receive the questionnaire in printed form. The following day, we forwarded hard copies of the questionnaire to all those who had requested it.

\section{The questionnaire}

The questionnaire, which served as our research tool, was based on a similar research carried out by Wilkens et al. (2004). It was translated into Slovenian and adapted to the situation in the Slovenian higher education environment. The questionnaire was initially subjected to pilot testing using a smaller sample. The first version of the questionnaire contained questions on the four basic KM processes (35 questions). The questions were modelled according to the 6-level Likert scale (from 1 - strongly disagree to 6 - strongly agree). Following the said pilot testing, we adapted certain questions according to the comments of respondents and thereby improved the questionnaire's comprehensibility.

\section{The final questionnaire consists of three parts, namely:}

Part I contains questions on organisational culture derived from the Organisational Culture Assessment Instrument (OCAI) which was developed and confirmed by Cameron and Quinn (1999) and is based on the theoretical CVF model. Different empirical research studies have found that CVF has both face and empirical validity, and helps incorporate many of the dimensions of organisational culture proposed by various researchers (Goodman et al. 2001; Kwan/Walker 2004; Lamond 2003; Zammuto et al. 1999). Howard (1998) in his study concludes that the CVF perspective provides a valid metric for understanding organisational cultures. It is based upon these arguments that we adopted the CVF to measure the organisational culture of the HEIs under study. Beside that we selected the typology according to Cameron and Quinn (1999) on account of the simplicity of the instrument (questionnaire) which constitutes the basis of this typology and is relatively simple and comprehensible. This instrument differs significantly from the majority of other instruments intended for the assessment of organisational culture, considering that it provides descriptions or affirmations to respondents, and not questions, with respondents assessing the extent to which their organisation corresponds to the given description. This means that such an instrument is internally quite consistent (reliable), considering that the answers reflect the respondents' personal attitude to a lesser degree. Another advantage of this instrument is its ability to assess the type of existing organisational culture. This typology allows for a systematic incorporation of a great number of dimensions of organisational culture. In addition, another advantage of this method is also that it allows for identification of the power and conformity of organisational culture on the basis of the studied data. There were numerous reasons for the selection of this particular typology, the main reason being that one can create the overall cultural profile of an institution with all six questions through the addition and measurement of averages. According to this typology, there exist four types of culture, namely: hierarchy culture, market culture, clan culture, and adhocracy 
culture. The list of the contents of the six dimensions is not comprehensive; however, different studies have shown that this model does provide a sufficiently detailed image of the type of culture existing in an organisation.

Part II contains questions related to the nature and characteristics of knowledge management. For the purposes of this research, this is defined by four processes, namely, creation, storage, transfer, and application of knowledge.

Part III contains questions on respondents' general demographic data (i.e. gender, academic status, and similar).

Out of 259 questionnaires sent (169 to HEI1 and 90 to HEI2), 82 were returned (54 from HEI1 and 28 from HEI2), which equates to a 30.5 percent response rate.

The limited size of the sample does not allow for generalization of the results obtained.

Table 1 shows sample characteristics. Considering the overall sample of 82 respondents, 54 or $65.8 \%$ are employed at HEI 1 and 28 or $34.2 \%$ at HEI2. A significant difference between the two groups of respondents was identified with regard to the question on the years of service completed with the same higher education institution. One can see that at HEI1 and at HEI2 as many as almost $76 \%$ of the respondents and as few as $21 \%$ of the respondents, respectively, have been employed by the institution for under 5 years. This is relevant information. We expect the co-workers who have been employed by the same institution for a longer period of time to have better developed all possible functions of knowledge management which are also dependent on formal and informal networks between employees.

Another important difference between the two groups is reflected in the number of days spent by employees at the institution. At HEI1, the respondents are approximately equally distributed among those who spend less than a day, those who spend from 1 to 2 days, those who spend 3 days, and those who spend more than 3 days a week at the institution. It is possible that such a low frequency of presence of these employees at the institution hinders the development of knowledge management processes; it may even be that it impedes, in particular, the transfer of knowledge, considering the low level of communication in real-time. In contrast to HEI1, as many as $50 \%$ of the respondents at HEI 2 spend more than 3 days a week at the institution. We may reasonably conclude that such a frequency of presence may well contribute to a greater trust among these employees; under the condition, of course, that the said frequency is not the result of organisational policy requiring such frequency, but the result of the different cultural values of these employees. 
Table 1. Sample characteristics

\begin{tabular}{|c|c|c|c|c|}
\hline & \multicolumn{2}{|c|}{ HEI1 } & \multicolumn{2}{|c|}{ HEI2 } \\
\hline & \multicolumn{2}{|c|}{$(n=54)$} & \multicolumn{2}{|c|}{$(\mathrm{n}=28)$} \\
\hline & $f$ & $\%$ & $f$ & $\%$ \\
\hline \multicolumn{5}{|c|}{ Gender } \\
\hline male & 32 & 59.26 & 15 & 53.57 \\
\hline female & 22 & 40.74 & 12 & 42.86 \\
\hline \multicolumn{5}{|c|}{ Academic title } \\
\hline teaching assistant & 17 & 31.48 & 11 & 39.29 \\
\hline lecturer & 15 & 27.78 & 3 & 10.71 \\
\hline senior lecturer & 8 & 14.81 & 1 & 3.57 \\
\hline assistant professor & 9 & 16.67 & 6 & 21.43 \\
\hline associate professor & 5 & 9.26 & 2 & 7.14 \\
\hline professor & 0 & 0.00 & 4 & 14.29 \\
\hline \multicolumn{5}{|c|}{ Employment era at HEI } \\
\hline less than 5 years & 41 & 75.93 & 6 & 21.43 \\
\hline 5 years or more & 13 & 24.07 & 19 & 67.86 \\
\hline \multicolumn{5}{|c|}{ Type of employment } \\
\hline full time & 33 & 60.00 & 23 & 82.14 \\
\hline half-time & 5 & 9.09 & 1 & 3.57 \\
\hline contract & 5 & 9.09 & 3 & 10.71 \\
\hline \multicolumn{5}{|c|}{ I weekly spend at HEI (on average) } \\
\hline less than a day & 15 & 27.78 & 0 & 0.00 \\
\hline $1-2$ days & 12 & 22.22 & 2 & 7.14 \\
\hline 3 days & 13 & 24.07 & 11 & 39.29 \\
\hline more than 3 days & 14 & 25.93 & 14 & 50.00 \\
\hline
\end{tabular}

\section{Results}

We analyzed the data with the SPSS 15.0 statistical package. The results are indeed interesting; however, owing to the indicated limitation (small sample), we have to consider them with great caution; also, we avoided the generalization of the findings outside the sample.

Tables 2 to 5 show descriptive statistics for individual variables. In addition, Cronbach's alpha test, whereby one measures questionnaire reliability or the reliability of its individual sets (knowledge generation, storage, transfer, and application), was used on each individual group of questions. All alpha values exceed 0.7 (from 0.818 to 0.878 ). We also analyzed the reliability of individual variables by applying the so-called item-to-total correlations. All variables with low correlation values were omitted from further analysis. Thus, we omitted 5 
out of 35 variables and henceforth continue with the analysis of 30 variables from the field of knowledge management.

Table 2. Statistics for Knowledge generation

\begin{tabular}{|c|c|c|c|c|c|c|}
\hline \multicolumn{3}{|c|}{ Cronbach's Alpha $=0,871$} & \multicolumn{2}{|c|}{ HEI1 } & \multicolumn{2}{|c|}{ HEI2 } \\
\hline \multicolumn{2}{|l|}{ Variable } & $\begin{array}{c}\text { Item-to- } \\
\text { total }\end{array}$ & Mean & $\begin{array}{c}\text { Std. } \\
\text { Deviation }\end{array}$ & Mean & $\begin{array}{c}\text { Std. } \\
\text { Deviation }\end{array}$ \\
\hline $\begin{array}{l}\text { My HEI actively supports } \\
\text { cooperation with other HEIs } \\
\text { on joint projects }\end{array}$ & $\mathrm{U} 1$ & 0.453 & 2.5962 & 1.4178 & 2.7143 & 1.4872 \\
\hline $\begin{array}{l}\text { My HEI constantly } \\
\text { benchmarks itself with the } \\
\text { best HEIs from its field. }\end{array}$ & $\mathrm{U} 2$ & 0.536 & 2.5385 & 1.3205 & 2.1071 & 1.1969 \\
\hline $\begin{array}{l}\text { My HEI regularly includes } \\
\text { well-known practitioners in } \\
\text { its educational process. }\end{array}$ & $\mathrm{U} 4$ & 0.654 & 2.9245 & 1.6154 & 2.4643 & 1.3739 \\
\hline $\begin{array}{l}\text { My HEI has well developed } \\
\text { research activities. }\end{array}$ & U5 & 0.690 & 2.9630 & 1.4003 & 3.1071 & 1.4991 \\
\hline $\begin{array}{l}\text { My HEI has a well developed } \\
\text { cooperation with companies } \\
\text { and other organisations on } \\
\text { joint R\&D projects. }\end{array}$ & U6 & 0.509 & 3.4231 & 1.3769 & 2.7778 & 1.4233 \\
\hline $\begin{array}{l}\text { My HEI encourages student } \\
\text { involvement in its research } \\
\text { activities. }\end{array}$ & $\mathrm{U} 7$ & 0.553 & 2.7963 & 1.2941 & 3.2143 & 1.5719 \\
\hline $\begin{array}{l}\text { My HEI encourages creation } \\
\text { of its own R\&D centres and } \\
\text { institutes by its employees. }\end{array}$ & U8 & 0.514 & 3.0556 & 1.4064 & 3.2963 & 1.5144 \\
\hline $\begin{array}{l}\text { My HEI encourages and } \\
\text { supports employees in their } \\
\text { further education. }\end{array}$ & U9 & 0.650 & 2.6111 & 1.5224 & 2.6071 & 1.3149 \\
\hline $\begin{array}{l}\text { My HEI encourages teaching } \\
\text { staff to work in an } \\
\text { international environment. }\end{array}$ & U10 & 0.664 & 2.5283 & 1.5517 & 2.7143 & 1.5119 \\
\hline $\begin{array}{l}\text { My HEI invites world-known } \\
\text { academics to give guest } \\
\text { lectures. }\end{array}$ & U11 & 0.686 & 2.7170 & 1.3356 & 2.8571 & 1.0440 \\
\hline
\end{tabular}

Knowledge generation was initially measured with 11 variables; we had to eliminate one variable (U3) because the value of the item-to-item correlation was too low. Table 2 thus considers 10 variables. Cronbach's alpha (0.871) attests to a good measuring reliability of the questionnaire. HEI1 respondents rated the knowledge generation variables with an average score of from 2.5283 to 3.4231 (on a scale from 1 to 6). Variable U6 received the highest, and variable U10 the lowest score. HEI2 respondents rated the knowledge 
generation variables with an average score of from 2.1071 to 3.2963 (on a scale from 1 to 6). Variable U8 received the highest, and variable U2 the lowest score.

Table 3. Statistics for knowledge storage

\begin{tabular}{|l|l|c|c|c|c|c|}
\hline \multicolumn{2}{|c|}{ Cronbach's Alpha $=0,818$} & \multicolumn{2}{c|}{ HEI1 } & \multicolumn{2}{c|}{ HEI2 } \\
\hline \multicolumn{2}{|c|}{ Variable } & $\begin{array}{l}\text { Item-to- } \\
\text { total } \\
\text { correlation }\end{array}$ & Mean & $\begin{array}{c}\text { Std. } \\
\text { Deviation }\end{array}$ & Mean & $\begin{array}{c}\text { Std. } \\
\text { Deviation }\end{array}$ \\
\hline $\begin{array}{l}\text { My HEI regularly stores } \\
\text { knowledge has an archive) } \\
\text { on the content and } \\
\text { implementation of the } \\
\text { educational process }\end{array}$ & S1 & 0.584 & 3.0294 & 1.3814 & 3.6667 & 1.4939 \\
\hline $\begin{array}{l}\text { My HEI regularly stores } \\
\text { knowledge has an archive) } \\
\text { on the content and } \\
\text { implementation of research } \\
\text { projects. S2 }\end{array}$ & 0.533 & 2.8065 & 1.3520 & 3.4583 & 1.3825 \\
\hline $\begin{array}{l}\text { My HEI has a well- } \\
\text { structured documentation of } \\
\text { employees competencies } \\
\text { and achievements. }\end{array}$ & S3 & 0.574 & 3.4242 & 1.4368 & 3.9231 & 1.2304 \\
\hline $\begin{array}{l}\text { My HEI always interviews } \\
\text { researchers after the end of } \\
\text { its biggest projects. }\end{array}$ & S6 & 0.674 & 3.9643 & 1.5749 & 4.6957 & 1.8448 \\
\hline $\begin{array}{l}\text { My HEI has an archive of } \\
\text { most important lectures and } \\
\text { researches as examples of } \\
\text { best practices. }\end{array}$ & S7 & 0.592 & 4.5484 & 1.6297 & 4.6957 & 1.6078 \\
\hline $\begin{array}{l}\text { My HEI has a well } \\
\text { developed and known } \\
\text { organisational identity. }\end{array}$ & S8 & 0.550 & 2.5116 & 1.3340 & 3.6667 & 1.3868 \\
\hline
\end{tabular}

Knowledge storage was initially measured with 8 variables; we had to eliminate two variables (S4 and S5) because the value of the item-to-item correlation was too low. Table 3 thus considers 6 variables. Cronbach's alpha (0.818) attests to a good measuring reliability of the questionnaire. HEI1 respondents rated the knowledge storage variables with an average score of from 2.5116 to 4.5484 (on a scale from 1 to 6). Variable S7 received the highest, and variable S8 the lowest score. HEI2 respondents rated the knowledge storage variables with an average score of from 3.4583 to 4.6957 (on a scale from 1 to 6). Variables S6 and $\mathrm{S} 7$ received the highest, and variable $\mathrm{S} 2$ the lowest score.

Knowledge transfer was initially measured with 9 variables; we had to eliminate two variables (P8 and P9) because the value of the item-to-item correlation was 
too low. Table 4 thus considers 7 variables. Cronbach's alpha (0.831) attests to the good measuring reliability of the questionnaire. HEI1 respondents rated the knowledge transfer variables with an average score of from 3.0189 to 3.6667 (on a scale from 1 to 6). Variable P1 received the highest, and variable P5 the lowest score. HEI2 respondents rated the knowledge transfer variables with an average score of from 3.1786 to 4.2500 (on a scale from 1 to 6). Variable P4 received the highest, and variable P6 the lowest score.

Table 4. Statistics for knowledge transfer

\begin{tabular}{|l|l|l|l|l|l|l|}
\hline \multicolumn{2}{|c|}{ Cronbach's Alpha $=0,831$} & \multicolumn{2}{c|}{ HEI 1 } & \multicolumn{2}{c|}{ Std. } \\
\hline \multicolumn{1}{|c|}{ Variable } & $\begin{array}{c}\text { HEI } \\
\text { total } \\
\text { correlation }\end{array}$ & Mean & Mean & $\begin{array}{c}\text { Std. } \\
\text { Deviation }\end{array}$ \\
\hline $\begin{array}{l}\text { My HEI has an efficient } \\
\text { system of coaching and } \\
\text { mentoring young } \\
\text { academics. P1 }\end{array}$ & 0.607 & 3.6667 & 1.4376 & 4.1071 & 1.5949 \\
\hline $\begin{array}{l}\text { My HEI enables young } \\
\text { academics to become aware } \\
\text { of different research topics. }\end{array}$ & P2 & 0.673 & 3.1346 & 1.4823 & 3.8519 & 1.2311 \\
\hline $\begin{array}{l}\text { My HEI actively supports } \\
\text { participation in multi- } \\
\text { disciplinary and inter- } \\
\text { disciplinary research teams. }\end{array}$ & P3 & 0.611 & 3.0980 & 1.4036 & 3.8571 & 1.2683 \\
\hline $\begin{array}{l}\text { My HEI encourages debate } \\
\text { on the main concepts and } \\
\text { terminology from research } \\
\text { and educational fields (i.e. } \\
\text { Wikipedia style). }\end{array}$ & P4 & 0.622 & 3.1176 & 1.3213 & 4.2500 & 1.6471 \\
\hline $\begin{array}{l}\text { My HEI regularly organizes } \\
\text { presentations and debates } \\
\text { on research achievements of } \\
\text { employees. }\end{array}$ & P5 & 0.542 & 3.0189 & 1.4870 & 3.2963 & 1.3535 \\
\hline $\begin{array}{l}\text { My HEI regularly organizes } \\
\text { internal educational } \\
\text { workshops on educational } \\
\text { methods and approaches. }\end{array}$ & P6 & 0.480 & 3.3704 & 1.6054 & 3.1786 & 1.4670 \\
\hline $\begin{array}{l}\text { My HEI has an efficient } \\
\text { computer based system to } \\
\text { support } \\
\text { between employees. }\end{array}$ & P7 & 0.525 & 3.4118 & 1.6270 & 3.5185 & 1.6955 \\
\hline
\end{tabular}

Knowledge application was measured with 7 variables. Cronbach's alpha (0.878) attests to a good measuring reliability of the questionnaire. HEI1 respondents rated the knowledge application variables with an average score of from 2.7308 to 3.4783 (on a scale from 1 to 6). Variable UP6 received the 
highest, and variable UP7 the lowest score. HEI2 respondents rated the knowledge application variables with an average score of from 2.8889 to 3.6800 (on a scale from 1 to 6). Variable UP6 received the highest, and variable UP1 the lowest score. Table 6 below shows the average scores given by respondents from both institutions to the individual areas of knowledge management.

Table 5. Statistics for knowledge application

\begin{tabular}{|l|l|c|c|c|c|c|}
\hline \multicolumn{2}{|c|}{ Cronbach's Alpha $=0,878$} & \multicolumn{2}{c|}{ HEI 1 } & \multicolumn{2}{c|}{ Std. } \\
\hline \multicolumn{2}{|c|}{ Variable } & $\begin{array}{c}\text { Item-to- } \\
\text { total } \\
\text { correlation }\end{array}$ & Mean & Mean & $\begin{array}{c}\text { Std. } \\
\text { Deviatio } \\
\text { n }\end{array}$ \\
\hline $\begin{array}{l}\text { My HEI successfully applies } \\
\text { best practices in the } \\
\text { educational process. }\end{array}$ & UP1 & 0,710 & 2,9200 & 0,9655 & 2,8889 & 1,0127 \\
\hline $\begin{array}{l}\text { My HEI successfully applies } \\
\text { best practices in research } \\
\text { projects. UP2 }\end{array}$ & 0,750 & 2,8431 & 1,1554 & 3,3214 & 1,3068 \\
\hline $\begin{array}{l}\text { My HEI successfully applies } \\
\text { its own past experience for } \\
\text { solving new challenges. }\end{array}$ & UP3 & 0,736 & 2,7451 & 1,2465 & 3,0769 & 0,9348 \\
\hline $\begin{array}{l}\text { My HEI successfully applies } \\
\text { disposable knowledge for } \\
\text { development of new } \\
\text { curricula. }\end{array}$ & UP4 & 0,687 & 2,8679 & 1,2563 & 3,1481 & 1,1335 \\
\hline $\begin{array}{l}\text { My HEI successfully applies } \\
\text { disposable knowledge for } \\
\text { development of new research } \\
\text { projects. }\end{array}$ & UP5 & 0,759 & 3,3137 & 1,3037 & 3,1600 & 1,0677 \\
\hline $\begin{array}{l}\text { My HEI successfully makes } \\
\text { use of disposable intellectual } \\
\text { potential. }\end{array}$ & UP6 & 0,499 & 3,4783 & 1,3782 & 3,6800 & 1,1075 \\
\hline $\begin{array}{l}\text { My HEI successfully applies } \\
\text { disposable knowledge for } \\
\text { marketing of its research and } \\
\text { educational potential. }\end{array}$ & UP7 & 0,548 & 2.7308 & 1.3448 & 3.2000 & 1.3540 \\
\hline
\end{tabular}

According to the measuring scale applied in the questionnaire, one can conclude that scores below 3 actually equal the mark poor and that scores over 3 somewhat equal the mark good. In accordance with the above, one can claim that knowledge storage and knowledge transfer are well-regulated in both institutions, and that HEI2's application of knowledge is good. Both institutions received poor scores in the area of knowledge generation, and HEI1's application of knowledge is poor. We present hereafter the types of organisational culture according to the OCAI model. Table 7 shows the average 
scores given to the different types of organisational culture. In order to facilitate understanding and, in particular, comparison between the two institutions, the results are also presented graphically in Figure 2.

Table 6. Average values of KM processes

\begin{tabular}{|l|c|c|}
\hline & HEI1 & HEI2 \\
\hline Knowledge Generation & 2.8153 & 2.7860 \\
\hline Knowledge Storage & 3.3807 & 4.0177 \\
\hline Knowledge Transfer & 3.2597 & 3.7228 \\
\hline Knowledge Application & 2.9856 & 3.2108 \\
\hline
\end{tabular}

Figure 1. Average values of KM processes

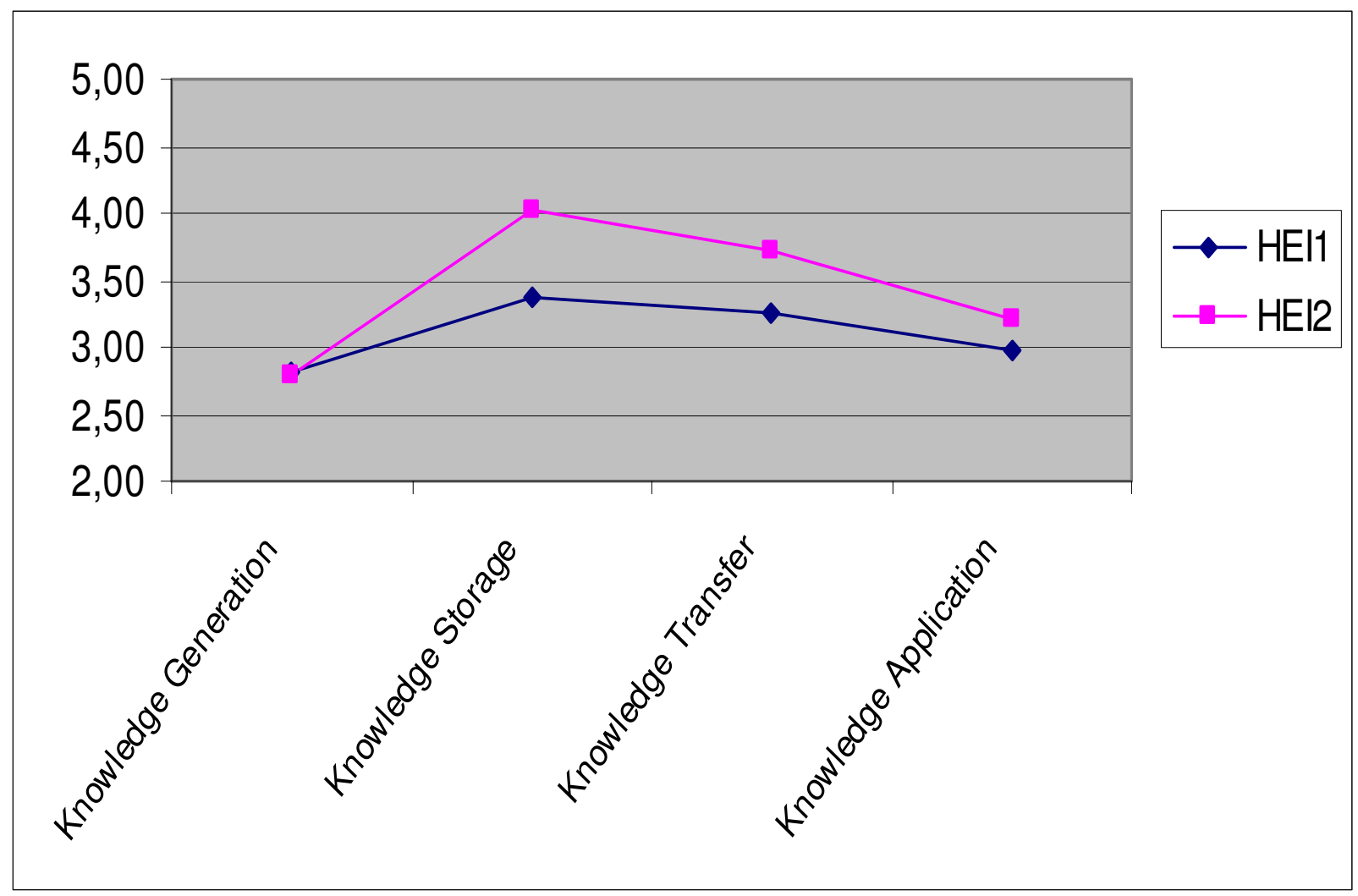

Table 7. Organisational cultural types scores based on the CVF

\begin{tabular}{|c|c|c|c|c|}
\hline & The Clan Culture & $\begin{array}{c}\text { The Adhocracy } \\
\text { Culture }\end{array}$ & $\begin{array}{c}\text { The Market } \\
\text { Culture }\end{array}$ & $\begin{array}{c}\text { The Hierarchy } \\
\text { Culture }\end{array}$ \\
\hline HEI1 & 20.46 & 25.85 & 31.67 & 22.03 \\
\hline HEI2 & 16.70 & 18.96 & 30.71 & 33.63 \\
\hline
\end{tabular}


Figure 2. Organisational cultural types in the two HEIs

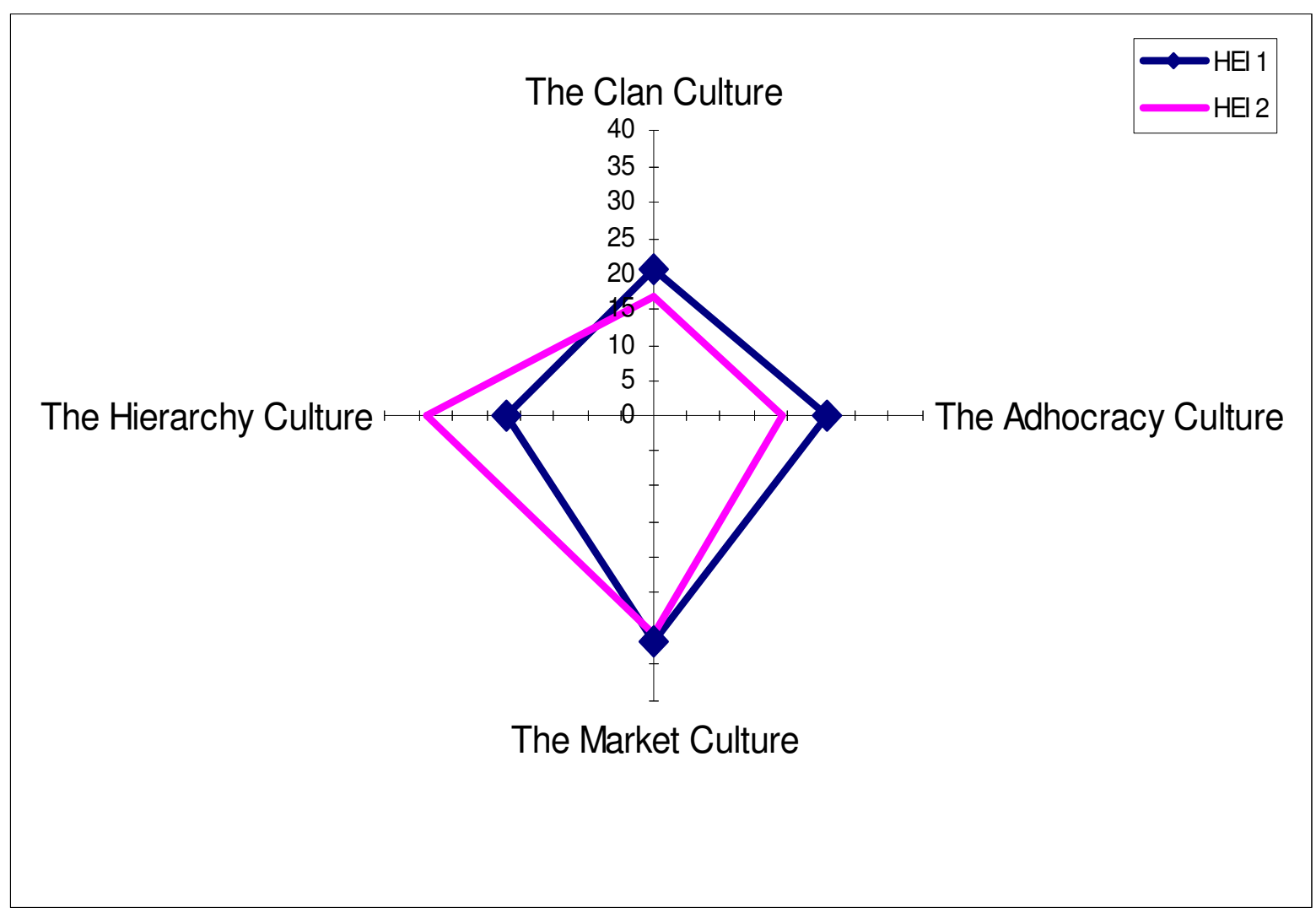

HEI1 is dominated by the market culture, with the other three culture types also being present. The clan culture is the least present. Otherwise, the difference between the hierarchy culture and the clan culture is small. HEI2 is dominated by the hierarchy culture, with the market culture following close behind. HEI2 is the least dominated by the clan culture and only slightly more by the adhocracy culture.

HEI1 has a highly developed market culture, which is most likely a consequence of the fact that it is a young institution. Young institutions must generate new knowledge in order to be successful and competitive. The ultimate goal is to differentiate oneself from others. The organisation is outward- and result-oriented. Quality work performance is its main concern. Employees of such organisations are competitive and goal-oriented. Heads are tough, demanding and competitive. The heads' and employees' common concerns are, in particular, reputation and performance. In the long term, the organisation focuses on the realization of measurable results. An increase in market share constitutes the most important criterion of performance. Only recently, HEI1 developed relatively rapidly from a small higher education institution into a stable and noted faculty at the national level with strong international connections. The adhocracy culture is the second most strongly present culture in the organisation. Creativity and innovation are a precondition for the organisation of this type to be able to rank among the successful. Such an 
organisation must react rapidly and be very active. This is also reflected in a substantial ICT support to the educational process. Namely, HEI1 is the first Slovenian faculty to have introduced e-education, a practice which is still being developed and improved. The organisation's working environment is dynamic, entrepreneurial and creative. Employees and heads alike are willing to expose themselves and undertake risks. In such an organisation, it does not suffice merely to be productive; what counts first and foremost is to be among the leaders in new knowledge, products and services. The organisation encourages individual incentives and autonomy, it is flexible and creative. Such a struggle for the leading position on the market has certain consequences, of course. The results show that this organisation is not employee-friendly. Employee fluctuation is high. In some cases, employees do not even know one another, primarily owing to the rambling growth in recent years. Labour force is being employed when the need arises. Unless this changes in the future, the institution will have to face some unpleasant consequences. We can conclude with the affirmation that from this point of view the higher education environment does not differ from the economy.

In contrast to HEI1, HEI2 is strongly dominated by the hierarchy culture. This result comes as no surprise, considering that it is a question of a member of the oldest Slovenian university with a rather rigid system. Such an organisation is inward-oriented and characterized by a constant need for a stable environment and control. A formalized and structured working environment is typical of HEI2. Procedures dictate the work of employees. Heads of such organisations excel in coordination and organisation, with work efficiency constituting their primary concern. It is rather important for the work to run smoothly. The organisation is determined and held together by formal rules. Long-term care is dedicated to the stability, efficiency and smooth running of work. Employees must be present at the faculty every day. Every single thing must be regulated, the processes are determined, and each change requires a considerable amount of time. Consequently study programmes change only very slowly. In sum, if changes do occur, they occur by themselves, provided, however, that they are absolutely necessary. In these times, however, even the most rigid systems must be ready to undergo changes. Consequently, HEI2 admits that changes will have to occur in the near future. Their attempts thereat are already reflected in their adjustment to the Bologna guidelines and their efforts to find suitable partners with whom to draw up new attractive study programmes. These changes must occur as soon as possible for HEI2 to become competitive on the Slovenian higher education market. Namely, new study programmes in Slovenia are being produced literally on an overnight basis.

These results are consistent with the study carried out by Kwan and Walker (2004) in Hong Kong's nine higher education institutions, whose findings also show that the market culture is typical, in particular, of younger higher 
education institutions, while older institutions are usually dominated by the hierarchy culture.

Numerous differences between HEI1 and HEI2 exist on account of the fact that the two institutions are at different points in the usual life cycle of an institution. The study of the organisational culture, organisational structure, and method of management of an organisation in relation to its life cycle was undertaken by numerous researchers (Shirokova 2009) who obtained similar results. Tables 8 and 9 present the analysis of the correlations between the different types of organisational culture and knowledge management processes.

Table 8. Correlation between organisational culture and KM processes (HEI1)

\begin{tabular}{|c|c|c|c|c|c|c|c|c|c|}
\hline & & Clan & $\begin{array}{l}\text { Ad- } \\
\text { hocracy }\end{array}$ & Market & $\begin{array}{l}\text { Hierar- } \\
\text { chy }\end{array}$ & $\begin{array}{l}\mathrm{K}_{-} \\
\text {generat }\end{array}$ & $\begin{array}{l}\mathrm{K}_{-} \\
\text {storage }\end{array}$ & $\begin{array}{l}\mathrm{K}_{-} \\
\text {transfer }\end{array}$ & $\begin{array}{l}\mathrm{K}_{-} \\
\text {appl }\end{array}$ \\
\hline \multirow[t]{3}{*}{ Clan } & $\begin{array}{l}\text { Pearson } \\
\text { Corr. }\end{array}$ & 1 & -.232 & $-.745^{* *}$ & $-.574 * *$ & -.182 & -.390 & $-.348^{*}$ & $-.316^{*}$ \\
\hline & $\begin{array}{l}\text { Sig. (2- } \\
\text { tailed) }\end{array}$ & & .091 & .000 & .000 & .222 & .089 & .018 & .039 \\
\hline & $\mathrm{N}$ & 54 & 54 & 54 & 54 & 47 & 20 & 46 & 43 \\
\hline \multirow[t]{3}{*}{$\begin{array}{l}\text { Ad- } \\
\text { hocracy }\end{array}$} & $\begin{array}{l}\text { Pearson } \\
\text { Corr. }\end{array}$ & -.232 & 1 & -.237 & -.237 & -.163 & -.113 & -.091 & .020 \\
\hline & $\begin{array}{l}\text { Sig. (2- } \\
\text { tailed) }\end{array}$ & .091 & & .085 & .084 & .272 & .634 & .549 & .897 \\
\hline & $\mathrm{N}$ & 54 & 54 & 54 & 54 & 47 & 20 & 46 & 43 \\
\hline \multirow[t]{3}{*}{ Market } & $\begin{array}{l}\text { Pearson } \\
\text { Corr. }\end{array}$ & $\begin{array}{l}.745^{* *} \\
\end{array}$ & -.237 & 1 & .213 & .285 & $.556^{*}$ & $.413 * *$ & $.360^{*}$ \\
\hline & $\begin{array}{l}\text { Sig. (2- } \\
\text { tailed) }\end{array}$ & .000 & .085 & & .121 & .052 & .011 & .004 & .018 \\
\hline & $\mathrm{N}$ & 54 & 54 & 54 & 54 & 47 & 20 & 46 & 43 \\
\hline \multirow[t]{3}{*}{$\begin{array}{l}\text { Hierar- } \\
\text { chy }\end{array}$} & $\begin{array}{l}\text { Pearson } \\
\text { Corr. }\end{array}$ & $\begin{array}{l}- \\
.574 * *\end{array}$ & -.237 & .213 & 1 & .102 & .138 & .168 & .079 \\
\hline & $\begin{array}{l}\text { Sig. (2- } \\
\text { tailed) }\end{array}$ & .000 & .084 & .121 & & .494 & .563 & .265 & .616 \\
\hline & $\mathrm{N}$ & 54 & 54 & 54 & 54 & 47 & 20 & 46 & 43 \\
\hline \multirow[t]{3}{*}{$\begin{array}{l}\mathrm{K}_{-} \\
\text {generat }\end{array}$} & $\begin{array}{l}\text { Pearson } \\
\text { Corr. }\end{array}$ & -.182 & -.163 & .285 & .102 & 1 & $.619 * *$ & $.443 * *$ & $.754 * *$ \\
\hline & $\begin{array}{l}\text { Sig. (2- } \\
\text { tailed) }\end{array}$ & .222 & .272 & .052 & .494 & & .004 & .003 & .000 \\
\hline & $\mathrm{N}$ & 47 & 47 & 47 & 47 & 47 & 20 & 43 & 40 \\
\hline \multirow[t]{3}{*}{$\begin{array}{l}\mathrm{K}_{-} \\
\text {storage }\end{array}$} & $\begin{array}{l}\text { Pearson } \\
\text { Corr. }\end{array}$ & -.390 & -.113 & $.556^{*}$ & .138 & $.619 * *$ & 1 & $.796 * *$ & $.646^{* *}$ \\
\hline & $\begin{array}{l}\text { Sig. (2- } \\
\text { tailed) }\end{array}$ & .089 & .634 & .011 & .563 & .004 & & .000 & .002 \\
\hline & $\mathrm{N}$ & 20 & 20 & 20 & 20 & 20 & 20 & 20 & 20 \\
\hline
\end{tabular}




\begin{tabular}{|l|l|l|l|l|l|l|l|l|l|}
\hline $\begin{array}{l}\text { K_ } \\
\text { transfer }\end{array}$ & $\begin{array}{l}\text { Pearson } \\
\text { Corr. }\end{array}$ & $-.348^{*}$ & -.091 & $.413 * *$ & .168 & $.443 * *$ & $.796 * *$ & 1 & $.579 * *$ \\
\cline { 2 - 10 } & $\begin{array}{l}\text { Sig. (2- } \\
\text { tailed) }\end{array}$ & .018 & .549 & .004 & .265 & .003 & .000 & & .000 \\
\cline { 2 - 10 } & $\mathrm{N}$ & 46 & 46 & 46 & 46 & 43 & 20 & 46 & 39 \\
\hline K_appl & $\begin{array}{l}\text { Pearson } \\
\text { Corr. }\end{array}$ & $-.316^{*}$ & .020 & $.360 *$ & .079 & $.754 * *$ & $.646 * *$ & $.579 * *$ & 1 \\
\cline { 2 - 10 } & $\begin{array}{l}\text { Sig. (2- } \\
\text { tailed) }\end{array}$ & .039 & .897 & .018 & .616 & .000 & .002 & .000 & \\
\cline { 2 - 10 } & $\mathrm{N}$ & 43 & 43 & 43 & 43 & 40 & 20 & 39 & 43 \\
\hline
\end{tabular}

** Correlation is significant at the 0.01 level (2-tailed).

* Correlation is significant at the 0.05 level (2-tailed).

Pearson's coefficients indicate strong correlations between individual types of culture as well as between individual processes which define knowledge management. Furthermore, the analysis of HEI1 demonstrates a statistically significant correlation between knowledge storage and market culture, between knowledge transfer and clan culture, between knowledge transfer and market culture, and, finally, also between knowledge application and clan culture, and between knowledge application and market culture.

Table 9. Correlation between organisational culture and KM processes (HEI2)

\begin{tabular}{|c|c|c|c|c|c|c|c|c|c|}
\hline & & Clan & $\begin{array}{l}\text { Ad- } \\
\text { hocracy }\end{array}$ & Market & $\begin{array}{l}\text { Hier- } \\
\text { archy }\end{array}$ & $\begin{array}{l}\mathrm{K}_{-} \\
\text {generat }\end{array}$ & $\begin{array}{l}\mathrm{K}_{-} \\
\text {storage }\end{array}$ & $\begin{array}{l}\mathrm{K}_{-} \\
\text {transfer }\end{array}$ & $\begin{array}{l}\mathrm{K}_{-} \\
\text {appl }\end{array}$ \\
\hline \multirow[t]{3}{*}{ Clan } & $\begin{array}{l}\text { Pearson } \\
\text { Corr. }\end{array}$ & 1 & .215 & $-.689 * *$ & -.125 & -.357 & -.026 & -.178 & -.204 \\
\hline & $\begin{array}{l}\text { Sig. (2- } \\
\text { tailed) }\end{array}$ & & .271 & .000 & .525 & .074 & .913 & .396 & .362 \\
\hline & $\mathrm{N}$ & 28 & 28 & 28 & 28 & 26 & 20 & 25 & 22 \\
\hline \multirow[t]{3}{*}{$\begin{array}{l}\text { Ad- } \\
\text { hocracy }\end{array}$} & \begin{tabular}{|l} 
Pearson \\
Corr. \\
\end{tabular} & .215 & 1 & .073 & $-.720 * *$ & -.007 & -.186 & -.112 & -.173 \\
\hline & $\begin{array}{l}\text { Sig. (2- } \\
\text { tailed) }\end{array}$ & .271 & & .712 & .000 & .973 & .433 & .593 & .440 \\
\hline & $\mathrm{N}$ & 28 & 28 & 28 & 28 & 26 & 20 & 25 & 22 \\
\hline \multirow[t]{3}{*}{ Market } & \begin{tabular}{|l} 
Pearson \\
Corr. \\
\end{tabular} & $-.689 * *$ & .073 & 1 & $-.552 * *$ & .184 & -.046 & .006 & -.164 \\
\hline & $\begin{array}{l}\text { Sig. (2- } \\
\text { tailed) }\end{array}$ & .000 & .712 & & .002 & .368 & .849 & .978 & .465 \\
\hline & $\mathrm{N}$ & 28 & 28 & 28 & 28 & 26 & 20 & 25 & 22 \\
\hline \multirow[t]{3}{*}{ Hierarchy } & \begin{tabular}{|l} 
Pearson \\
Corr. \\
\end{tabular} & -.125 & $-.720 * *$ & $-.552 * *$ & 1 & .067 & .147 & .179 & .378 \\
\hline & $\begin{array}{l}\text { Sig. (2- } \\
\text { tailed) }\end{array}$ & .525 & .000 & .002 & & .745 & .536 & .391 & .082 \\
\hline & $\mathrm{N}$ & 28 & 28 & 28 & 28 & 26 & 20 & 25 & 22 \\
\hline
\end{tabular}




\begin{tabular}{|c|c|c|c|c|c|c|c|c|c|}
\hline \multirow[t]{3}{*}{$\begin{array}{l}\mathrm{K}_{-} \\
\text {generat }\end{array}$} & $\begin{array}{l}\text { Pearson } \\
\text { Corr. }\end{array}$ & -.357 & -.007 & .184 & .067 & 1 & $-.528^{*}$ & -.017 & $.565^{* *}$ \\
\hline & $\begin{array}{l}\text { Sig. (2- } \\
\text { tailed) }\end{array}$ & .074 & .973 & .368 & .745 & & .024 & .937 & .008 \\
\hline & $\mathrm{N}$ & 26 & 26 & 26 & 26 & 26 & 18 & 23 & 21 \\
\hline \multirow[t]{3}{*}{$\begin{array}{l}\mathrm{K}_{-} \\
\text {storage }\end{array}$} & $\begin{array}{l}\text { Pearson } \\
\text { Corr. }\end{array}$ & -.026 & -.186 & -.046 & .147 & $-.528 *$ & 1 & $.635^{* *}$ & .074 \\
\hline & $\begin{array}{l}\text { Sig. (2- } \\
\text { tailed) }\end{array}$ & .913 & .433 & .849 & .536 & .024 & & .003 & .770 \\
\hline & $\mathrm{N}$ & 20 & 20 & 20 & 20 & 18 & 20 & 20 & 18 \\
\hline \multirow[t]{3}{*}{$\begin{array}{l}\mathrm{K}_{-} \\
\text {transfer }\end{array}$} & $\begin{array}{l}\text { Pearson } \\
\text { Corr. }\end{array}$ & -.178 & -.112 & .006 & .179 & -.017 & $.635^{* *}$ & 1 & .121 \\
\hline & $\begin{array}{l}\text { Sig. (2- } \\
\text { tailed) }\end{array}$ & .396 & .593 & .978 & .391 & .937 & .003 & & .601 \\
\hline & $\mathrm{N}$ & 25 & 25 & 25 & 25 & 23 & 20 & 25 & 21 \\
\hline \multirow[t]{3}{*}{$\overline{\text { K_appl }}$} & $\begin{array}{l}\text { Pearson } \\
\text { Corr. }\end{array}$ & -.204 & -.173 & -.164 & .378 & $.565^{* *}$ & .074 & .121 & 1 \\
\hline & $\begin{array}{l}\text { Sig. (2- } \\
\text { tailed) }\end{array}$ & .362 & .440 & .465 & .082 & .008 & .770 & .601 & \\
\hline & $\mathrm{N}$ & 22 & 22 & 22 & 22 & 21 & 18 & 21 & 22 \\
\hline
\end{tabular}

** Correlation is significant at the 0.01 level (2-tailed).

* Correlation is significant at the 0.05 level (2-tailed).

In relation to HEI2 as well, Pearson's coefficients indicate strong correlations between certain types of culture as well as between individual processes which define knowledge management. In contrast to HEI1, the analysis of HEI2 demonstrates that none of the types of organisational culture is in a statistically significant correlation with any of the knowledge management processes.

In their study of Malaysian public universities, Sharimllah et al. (2007) demonstrated the existence of strong correlations between the market and adhocracy cultures and knowledge management processes. We cannot claim the same for our research in relation to HEI2; as regards HEI1, however, we can say that statistically significant correlations between the adhocracy culture and knowledge management processes are non-existent. As regards the market culture in relation to HEI1, however, our research also demonstrates a statistically significant correlation between the market culture and all the knowledge management processes, with the exception of knowledge generation.

\section{Conclusion}

One can see in the light of knowledge management processes that the individual processes are highly correlated with one another. This can readily be explained, provided we understand the importance of the individual processes. It is difficult sometimes to distinguish between and precisely define how to classify 
individual factors. Thus, one could understand an efficiently computerized system either as a good means of transfer, or as a means of information storage, or even as an important knowledge acquisition factor. Another such example is, for instance, the publication of staff achievements in publications, articles, and similar. On the one hand, it is a question of a typical example of knowledge transfer, while, on the other,the publication of results also constitutes knowledge storage.

The most relevant difference between our study and other studies is reflected in the fact that we have failed to identify any significant correlations between certain types of organisational culture and knowledge management processes. (Lawson 2003; Sharimllah et al. 2007). It is true that our research did identify a statistically significant correlation between knowledge storage and market culture, between knowledge transfer and clan culture, between knowledge transfer and market culture, and, finally, between knowledge application and clan culture, and between knowledge application and market culture, however, only in the case of HEI1. The analysis of HEI2 demonstrated that none of the types of organisational culture is in a statistically significant correlation with any of the knowledge management processes.

There are some limitations that need to be pointed out in order to set the boundaries and limits of this research.

1. The sampling procedure: we had a non - probability sample. Therefore generalization is not possible, not because of the low response rate only but also because of the sampling procedures and sample.

2. We focused on teaching staff for the reasons already discussed. Still, this focus is a limitation itself.

3. We translated and adapted a questionnaire. Translations are always culture-bound bounded and therefore validity and reliability need to be read from this point of view.

4. Cultural 'specifics' and traditions of Slovenian HEI were not specifically addressed, therefore we can assume some impact of these factors on responses. However we can also take the perspective that globalization has influenced the cultures of HEI, meaning that academics are connected, work together and collaborate in different forms and various contents. We can only speculate on how cultural elements differ among HEIs in Europe and world-wide. Also forms of governance and management seem to be similar. From this point of view, it makes sense to do the research as it is presented here.

5. However, reading the findings and conclusions requires also taking these limitations into account.

It is true; however, that the results should also be interpreted in compliance with the size of the sample, which in our case was small. It is also true that a $30 \%$ 
response rate constitutes a high rate for the Slovenian environment, particularly if we take into account e-surveys which, according to the statements of numerous researchers, are less effective in the Slovenian environment than classical surveys via mail. Our assumption was that the method of survey does not affect the response rate of the higher education teaching staff. Although the differences between our study and foreign studies may be conditional upon the methodological elements, one can also interpret them in the light of cultural specificities - i.e. a rapidly growing economy where the HE sector is in a turmoil, struggling for new points of stability and higher international visibility. HEIs are known for the cult of the individual expert, which is somehow at odds with a knowledge based culture oriented towards cooperation and knowledge sharing. The results of our research bring some new pieces of knowledge about culture - KM relation within HEIs. The aforementioned cult does not seem so prohibitive for HEI's effectiveness. In the future, research could be directed towards collecting and analyzing responses about $\mathrm{KM}$ and cultural typologies across a number of departments and faculties in order to build up a more complete 'picture' of the dynamic knowledge processes within HEIs and their relation to organisation culture. Also, issues such as organisational structure, reward system, and management style, which are constituent parts of organisational culture, can be addressed in more detail especially regarding tacit knowledge storage, knowledge creation and innovation within HEIs.

\section{References}

Alavi, M./Kayworth, T.R./Leidner, D.E. (2006): An empirical examination of the influence of organisational culture on knowledge management practices. Journal of Management Information Systems, 22, 3, 191-224.

Balthazard, P.A./Cooke, R.A. (2004): Organisational Culture and Knowledge Management Success: Assessing The Behavior-Performance Continuum. Proceedings of the 37th Hawaii International Conference on System Sciences, available http: //www.computer.org/portal/web/csdl/doi/10.1109/HICSS.2004.1265577, 28. 11. 2009.

Bartell, M. (2003): Internationalization of universities: a university culture-based framework. Higher Education, 45, 43-70.

Bates, T. (1997, June): Restructuring the university for technological change. Paper presented at The Carnegie Foundation for the Advancement of Teaching, What Kind of University, London, GB.

Beckmann, A./Cooper, C. (2004): Globalization', the new managerialism and education: Rethinking the purpose of education in Britain, The Journal for Critical Educational Policy Studies, 2(2) http://www.jceps.com/?pageID=article\&articleID=31.

Brooking, A. (1998): Intellectual capital: core asset for the third millennium enterprise. London: International Thomson Business Press.

Cameron, K.S./Quinn, R.E. (1999): Diagnosing and changing organisational culture. Reading, MA: Addison-Wesley, Inc. 
Clark, B.R. (ed.). (1984): Perspectives on higher education: Eight disciplinary and comparative views. Berkeley, CA: University of California Press.

Cloete, M.,/Snyman, R. (2003): The enterprise portal - is it knowledge management? Aslib Proceedings. 55, 4, 234-242.

Dakhli, M./De Clerko, D. (2004): Human capital, social capital, and innovation: a multicountry study, Entrepreneurship and Regional Development, 16, 2, 107-128.

Davenport, T.H./Prusak, L. (2000): Working Knowledge: How Organisations Manage What They Know. Boston, Massachusetts: Harvard Business School Press.

Dawson, R. (2000): Developing knowledge-based client relationship: The future of professional services. Boston: Butterworth-Heinemann.

Deal, T.E./ Kennedy, A.A. (1982): Corporate cultures. Reading, MA: Addison-Wesley.

De Long/David W./Fahey, L. (2000): Diagnosing Cultural Barriers to Knowledge Management. Academy of Management Executive, 14, 4, 113-127.

Donaldson, L. (2001): Reflections on knowledge and knowledge-intensive firms. Human Relations, 54, 7, 955-963.

Drucker, P.F. (1993): Post capitalist society. New York: Harper-Business.

Drucker, P.F. (2001): Managerski izzivi v 21. stoletju. Ljubljana: GV.

Duffy, J. (2001): The tools and technologies needed for knowledge management. Information Management Journal. 35, 1, 64-67.

Garvin, D.A. 1993: Building a learning organisation. Harvard Business Review 71, 4, 78-91.

Geng, Q.(ed.) (2005): Comparative knowledge management: A pilot study of Chinese and American universities. Journal of American Society for Information Science and Technology, 56, 10, 1031-1044.

Goddard, A. (1998): Facing up to market forces. Times Higher Education Supplement, 13, 67.

Goodman, E.A./Zammuto, R.F./Gifford, B.D. (2001): The competing values framework: Understanding the impact of organisational culture on the quality of work life. Organisation Development Journal, 19, 3, 58-67.

Goldsmith, R.E. (2004): Current and future trends in marketing and their implications for the discipline, Journal of Marketing Theory and Practice 12, 4, 10-16.

Grant, R.M. (1991): "The resource based theory of competitive advantage: implications for strategy formulation", California Management Review, 33, 3, 14-35.

Grant, R.M. (1996): Toward a knowledge-based theory of the firm. Strategic Management Journal 17, 2, 109-122.

Gupta, A.K./Govindarajan, V. (2000): Knowledge management's social dimension: Lessons from Nucor Steel. Sloan Management Review, 42, 1, 71-81.

Handy, C. (1993): Understanding organisations (4th ed.). London: Penguin Books.

Hemsley-B.J./Oplatka, I. (2006): Universities in a competitive global marketplace: A systematic of the literature on higher education marketing, International Journal of public sector management 19, 4, 316-338. 
Howard, L.W. (1998): Validating the competing values model as a representation of organisational cultures. International Journal of Organisational Analysis, 6, 3, 231-250.

Israelsohn, C. (1999): Making the Connections. Charter. 70, 5, 48-50.

Karoliny, Z./Farkas, F./Poór, J. (2009): In focus: Hungarian and Central Eastern European characteristics of human resource management - an international comparative survey. Journal for East European Management Studies; 14, 1, 9-47.

Kermally, S. (2007): Managing knowledge without tears, knowledge management for beginners. Http://www.knowledgeboard.com/library/kmfb_sultan_kermally_01.pdf, June 2007.

Kidwell, J.J./Vander Linde, K.M./Johnson, S.L. (2000): Applying corporate knowledge management practices in higher education. EDUCAUSE Quarterly, 23, 4, 28-33.

Kogut, B./Zander, U. (1996): What do firms do? Coordination, identity and learning. Organisation science 7, 5, 502-518.

Kwan, P./Walker, A. (2004): Validating the competing values model as a representation of organisational culture through inter-institutional comparisons. Organisational Analysis, 12, 1, 21-37.

Lamond, D. (2003): The value of Quinn's competing values model in an Australian context. Journal of Managerial Psychology, 18, 1, 46-59.

Laudon, K./Laudon, J. (1999): Management information systems-organisation and technology in the networked enterprise. Englewood Cliffs, NJ: Prentice Hall.

Lawson, S. (2003): Examing the relationship between organisational culture and knowledge management. Unpublished doctoral dissertation, The Wayne Huizenga School of Business and Entrepreneurship, Nova Southeastern University, Florida.

Levine, A.E. (2000): The future of colleges: 9 inevitable changes. Chronicle of Higher Education.

Macintosh, A. (1999): Knowledge management. Http://www.aiai.ed.ac.uk/ research/planning. html Retrieved on August 2007.

Marquardt, M.J. (1996): Building the learning organisation. New York: McGraw-Hill.

Meyer, H.D. (2002): The new managerialism in education management: Corporatization or organisational learning? Journal of Educational Administration, 40, 6, 534-551.

Middlehurst, R./Woodfield, S. (2006): Quality review in distance learning: Policy and practice in five countries. Tertiary Education and Management, 12, 4, 37-58.

Morris, H. (2000): Three waves of information portals for knowledge management, KM World, 9, 6, 8-9.

Nonaka, I. (1991): The knowledge creating company. Harvard Business review: 69, 6, 96-104.

Oplatka, I. (2004): The characteristics of the school organisation and the constraints on market ideology in education: an institutional view, Journal of Education Policy 19, 2, 143 161.

Pillania, R.K. (2008): “Knowledge storage and access in automotive components' SMEs in India" International Journal of Electric and Hybrid Vehicles. 1, 4, 333-341. 
Prahalad, C.K./Hamel G. (1990): The Core Competence of the corporation. Harvard Business Review, 68, 3, 79-91.

Probst, G.(ed.) (1999): Managing knowledge: Building Blocks of Success. Chichester: John Wiley \& Sons.

Pundziene, A./Kundrotas, V./Lydeka, Z. (2006): Management challenges in rapidly growing Lithuanian enterprises. Baltic Journal of Management, 1, 1, 34-48.

Quinn, R.E./Rohrbaugh, J. (1981): A Competing Values Approach to Organisational Effectiveness, Public Productivity Review, 5, 122-140.

Quintas, P./Lefrere, P/Jones, G. (1997): Knowledge management: a strategic agenda. Long Range Planning, 30, 3, 385-391.

Rowley, J. (2000): Is higher education ready for knowledge management? International Journal of Educational Management, 14, 7, 325-333.

Salmi, J. (2002): Constructing knowledge societies: New challenges for tertiary education. Washington, DC: World Bank. Retrieved July 1, 2003, from http://wwwwds.worldbank.org/servlet/DSContentServer/WDSP/IB/2002/11/01/00094946_02102 204203142/endered/PDF/multi0page.pdf.

Schein, E.H. (1992): Organisational culture and leadership. San Francisco: The Jossey-Bass Inc.

Serban, A.M./Luan, J. (eds.) (2002): Knowledge management: Building a competitive advantage in higher education.New Directions for Institutional Research, No. 113. San Francisco: Jossey-Bass.

Sharimllah D.R./Chong, S.C./Lin, B. (2007): Organisational culture and KM processes from the perspective of an institution of higher learning. Int. J. Management in Education, 1, $1 / 2,57-79$.

Shirokova, G. (2009): Organisational life-cycle: The characteristics of developmental stages in Russian companies created from scratch. Journal for East European Management Studies; 14, 1, 65-85.

Spender, J.C. (1994): "Organisational knowledge, collective practice and penrose rent." International Business Review, 3, 4, 353-367.

Spender, J.C./Grant, R.M. (1996): Knowledge and the firm: overview. Strategic Management Journal. 17, 5-9.

Sporn, B. (1999): Managing university culture: an analysis of the relationship between institutional culture and management approaches. Higher Education, 32, 41-61.

Suresh, R (2007): Knowledge management: an overview. Http://www.knowledgeboard.com/ cgi-bin/library.cgi?action=detail\&id=1275, June 2007.

Sveiby, K.E. (1997): The new organisational wealth: managing and measuring knowledge based assets. San Francisco, CA: Berrett-Koehler Publishers.

Sveiby, K.E. (1998): The invisible balance sheet, available at: www.sveiby.com/articles/ IntangAss/denosynl.htm (accessed 5th of September 2010).

Syed-Ikhsan, S.O.S./Rowland, F. (2004): Knowledge management in a public organisation: A study on the relationship between organisational elements and the performance of knowledge transfer. Journal of Knowledge Management, 8,2, 95-111. 
Teichler, U.1. (2004): The changing debate on internationalization of higher education, Higher Education, 48,1, 5-26.

Tierney, W.G. (1988): Organisational culture in higher education: defining the essentials. Journal of Higher Education, 95, 2-21.

Tippins, M. (2003): Implementing knowledge management in academia: Teaching the teachers. The International Journal of Educational Management, 17, 7, 339-345.

Tylor, E.B. (1871): Primitive culture: Researches into the development of mythology, philosophy, religion, art and custom, vol. 1. London: John Murray.

Wiig, K.M. (1993): Knowledge management foundations. TX: Schema Press.

Wiig, K.M. (1997): Knowledge management: An introduction and perspective. The Journal of Knowledge Management, 1, 1, 6-14.

Wilkens, U./Menzel, D./Pawlowsky, P. (2004): Inside the black-box: Analysing the generation of core competencies and dynamic capabilities by exploring collective minds. An organisational learning perspective. Management Revue, 15, 1, 8-26.

Wind, J./Main, J. (1999): Driving change. New York: The Free Press.

Zammuto, R.F./Gifford, G./Goodman, E.A. (1999): Managerial ideologies, organisation culture and the outcomes of innovation: a competing values prospective.

Zsóka, A.N.( 2007): The role of organisational culture in the environmental awareness of companies. Journal for East European Management Studies; 12, 2, 109-131 